\title{
A Case of Soft Tissue Metastasis in Contralateral Submandibular Space by Regional Recurrence of Lower Lip Cancer
}

\author{
Seok Jung Hong ${ }^{1}$, Sung Hwan $\mathrm{Lim}^{1}$, Eun Ju Kim², and Seung Woo Kim ${ }^{1}$ \\ ${ }^{1}$ Departments of Otolaryngology-Head and Neck Surgery, ${ }^{2}$ Pathology, Veterans Health Service Medical Center, Seoul, Korea
}

\section{하구순암의 구역 재발로 반대편 악하 공간에 발생한 연조직 전이 1예}

홍석정 ${ }^{1} \cdot$ 임성환 $^{1} \cdot$ 김은주 $^{2} \cdot$ 김승우 $^{1}$

중앙보훈병원 이비인후과, ${ }^{1}$ 병리과 ${ }^{2}$

Received April 26, 2017
Revised June 14, 2017
Accepted June 26, 2017
Address for correspondence
Seung Woo Kim, MD
Department of Otolaryngology-
Head and Neck Surgery,
Veterans Health Service
Medical Center,
53 Jinhwangdo-ro 61-gil,
Gangdong-gu, Seoul 05368, Korea
Tel +82-2-2225-1384
Fax+82-2-2225-1385
E-mail entzzang1020@hanmail.net

Received April 26, 2017

Revised June 14, 2017

Accepted June 26, 2017

Seung Woo Kim, MD

Department of Otolaryngology-

Head and Neck Surgery,

ans Health Service

53 Jinhwangdo-ro 61-gil,

Gangdong-gu, Seoul 05368, Korea

E-mail entzzang1020@hanmail.net
The most common cause of treatment failure in oral cavity cancer is when it is found to have local recurrence, usually occurring in the ipsilateral cervical lymph node. On the contrary, it is extremely rare to find local recurrence in soft tissue metastasis (STM) in the contralateral neck. Furthermore, lung cancer and malignant lymphoma are most commonly confined to their primary sites. The poor general condition increases the likelihood of STM, which indicates bad prognosis. A 72-year-old man with a hard and fixed mass on the right submandibular space visited our clinic. He had received a wide excision with local flapreconstruction for squamous cell carcinoma in the left corner of lower lip 18 months ago. We performed the wide excision with bilateral selective neck dissection (I-III), and he was finally diagnosed as STM from contralateral lip cancer. We report this unique and rare disease entity with a literature review.

Korean J Otorhinolaryngol-Head Neck Surg 2018;61(12):702-4

Key Words Contralateral neck · Neoplasm recurrence, local $\cdot$ Soft tissue neoplasm.

\section{서 론}

구순암은 위치적 특성 때문에 조기에 진단되며, 5년 생존율 은 약 $95 \%$ 정도이다. ${ }^{1)}$ 이 중 약 $11 \%$ 에서 재발이 발생하고, 그 형태는 대부분 국소 재발이다.1,2) 구역 재발은 동측 경부 림프 절에서 주로 발생하며, 반대측 경부에 연조직 전이 형태로 나 타나는 경우는 매우 드물다. ${ }^{2} 18$ 개월 전에 좌측 하구순암의 근치 수술 후 재발 없이 지내던 72세 남자 환자가 우측 악하 공간의 종물을 주소로 내원하였다. 최종적으로 좌측 하구순 암의 연조직 전이로 진단된 매우 드문 증례를 문헌고찰과 함 께 보고하고자 한다.

This is an Open Access article distributed under the terms of the Creative Commons Attribution Non-Commercial License (https://creativecommons.org/licenses/by-nc/4.0) which permits unrestricted non-commercial use, distribution, and reproduction in any medium, provided the original work is properly cited.

\section{증 례}

75세 남자 환자가 내원 3개월 전부터 시작된 우측 악하 공간 의 동통성 및 고정성 종물을 주소로 내원하였다. 과거력상 18 개월 전 좌측 하구순에 발생한 1기 편평상피세포 암종으로 광 범위 절제술 및 국소 피판술을 시행받았으며, 재발 없이 추적 관찰 중이었다. 신체검사에서 우측 악하 공간에 $2 \times 3 \mathrm{~cm}$ 크 기의 고정되고, 단단한 압통성 종물이 촉지되었다(Fig. 1). 경 부 초음파검사에서 우측 악하 공간에 붙어 있는 3 개의 종물 들이 관찰되었다. 각각의 종물들은 약 $2.4 \times 2.6,0.8 \times 1.1,1.2$ $\times 1.5 \mathrm{~cm}$ 의 크기로 경계는 비교적 뚜렷하고 내부에 혼합 에 코음영을 보이는 양상이었다(Fig. 2A). 경부 전산화 단층촬 영에서는 우측 악하 공간 전외측 부위에 주변부 조영 증강을 동반하는 저음영의 종물 소견이었다(Fig. 2B). 초음파 유도하 
세침흡입검사에서는 편평상피세포 암종으로 보고되었다. 양 전자 방출단층촬영에서 우측 악하 공간에 과대사 병변이 관 찰되었고, 원격 전이의 소견은 없었다(Fig. 2C).

이상의 소견들을 종합하여 좌측 하구순암에 의한 반대측
경부 림프절 재발로 진단하고, 광범위 절제술 및 양측 선택적 경부 림프절 절제술(level I-III)을 계획하였다. 수술 소견은 우측 악하 공간에 있는 종물이 피부와 피하조직과 심한 유 착이 있었고, 광견근 및 피하조직의 침범이 의심되어 절제연에

Fig. 1. External photographs. It shows a $2 \times 3 \mathrm{~cm}$ sized hard and fixed mass at right submandibular space (arrowheads) (A). It shows the previous operation scar at the left corner of lip (arrows) (B).
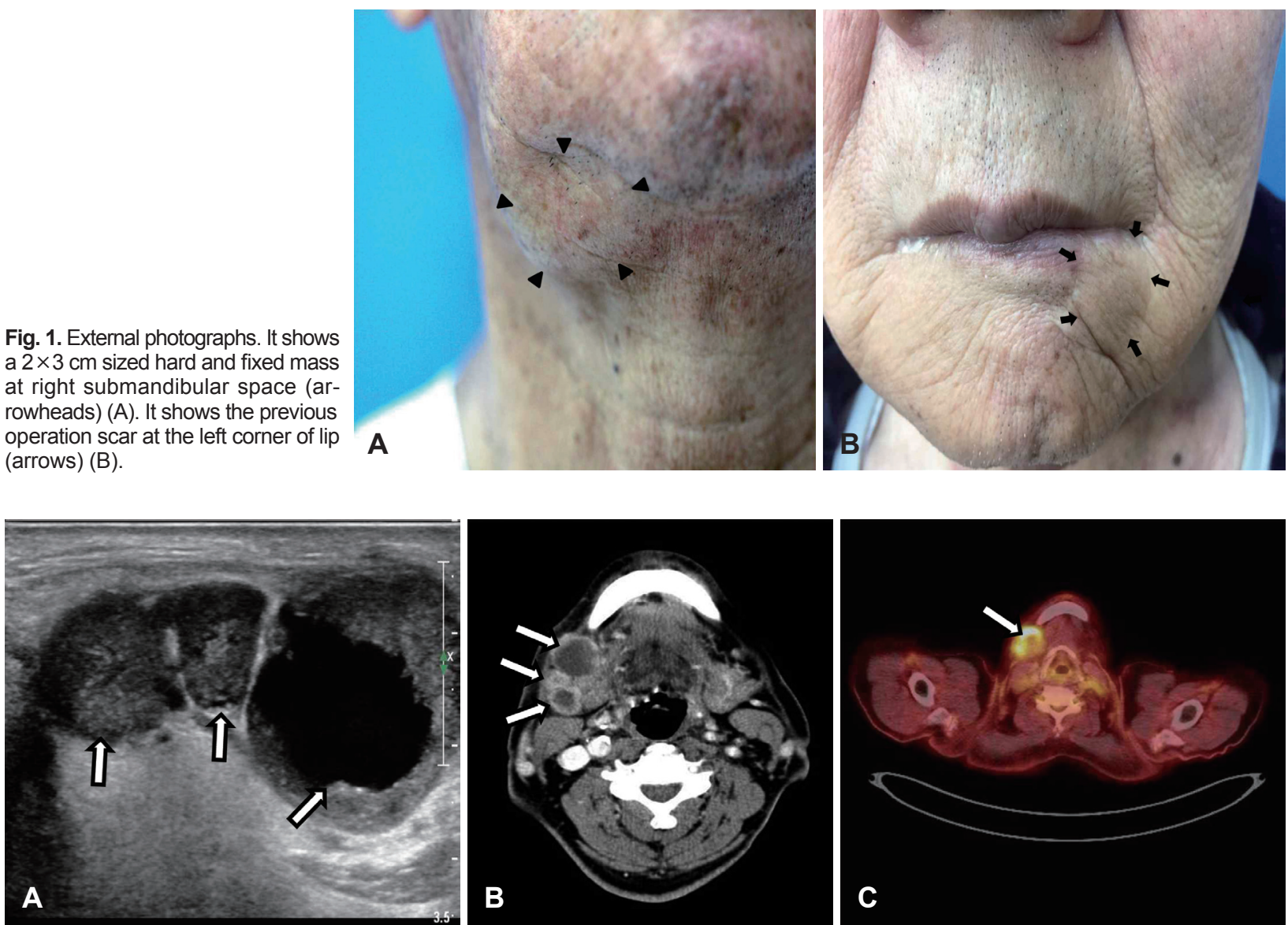

Fig. 2. Radiologic findings. Neck ultrasonography shows $2.4 \times 2.6,0.8 \times 1.1$, and $1.2 \times 1.5 \mathrm{~cm}$ sized hypoechoic masses with relatively well-defined margin above the right submandibular gland (arrows) (A). The enhanced CT scan shows round masses with rim enhancing on right submandibular space (arrows) (B). The ${ }^{18}$ F-FDG PET-CT scan shows strong FDG uptake on the right submandibular space and the standard uptake value is 10.3 (arrow) (C). ${ }^{18}$ F-FDG PET-CT: F-18-fluorodeoxyglucose positron emission tomography-computed tomography, FDG: fluorodeoxyglucose.
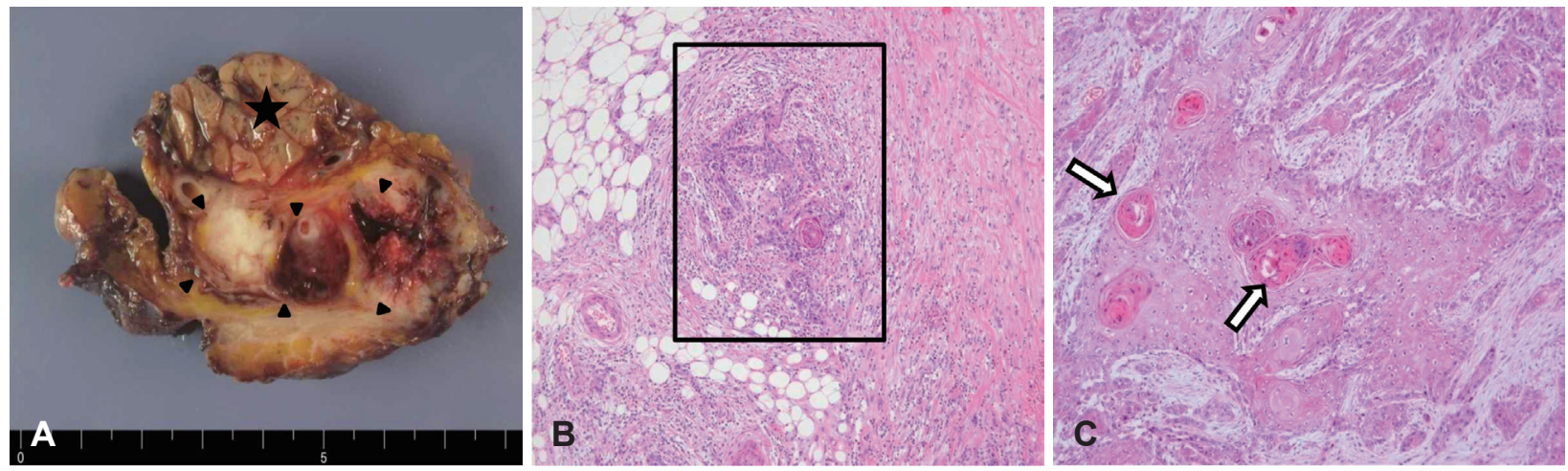

Fig. 3. Pathologic findings. The cut surface of specimen shows that the mass is located on the soft tissues (arrowheads) without signs of invasion on the submandibular gland (black star) (A). Microscopic findings show the tumor in the soft tissue deposit without lymphoid cells (square) (hematoxylin-eosin, $\times 10)(B)$. The lesion is consistent with squamous cell carcinoma, including whirling keratin pearl (arrows) (hematoxylin-eosin, $\times 100)(C)$. 
서 동결절편검사를 시행하여, 모두 음성임을 확인하였다. 그 외에도 악설골근, 설골설근 및 하악골 골막 등도 침범하였다. 침범된 구조물들을 일괴로 제거하였지만, 안면신경의 변연하 악 분지는 불가피하게 희생하였다. 최종 조직검사상 종물은 우측 악하선을 침범하지 않고, 주로 주변 연조직에 위치해 있 으며(Fig. 3A), 종양 주변으로는 림프구가 발견되지 않아서 일 반적인 림프절 전이와 다른 양상이었다(Fig. $3 \mathrm{~B}$ and C). 이런 병리학적 소견들을 종합하여 환자는 악하 공간에 연조직 전 이를 일으킨 편평상피세포 암종으로 최종 진단되었다. 술 후 $63 \mathrm{~Gy}$ 의 방사선 치료를 시행받았으며, 14 개월이 지난 현재까 지 재발 없이 추적 관찰 중이다.

\section{고 찰}

원발암에서 발생한 연조직 전이는 발생 빈도가 $0.2 \sim 0.8 \%$ 정 도로 극히 드물며, ${ }^{3,4}$ 흔한 원발지는 폐암 및 악성 림프종 등 이다. ${ }^{3)}$ 두경부암 중에서는 후두 및 하인두 등에서 연조직 전 이가 일부 보고되어 있으며, ${ }^{4)}$ 구강암에서 발생한 연조직 전이 는 2예가 보고되어 있다.,5) 이 중 1 예는 설암에서 보고되었으 며, 다른 1 예는 구강의 어느 부위인지는 언급되어 있지 않았 다. ${ }^{5)}$ 이렇게 발생이 드문 이유는 연조직이 젖산과 아드레날 린 작용 수용체와 같은 항암 대사산물을 생성하여 종양의 침범을 억제하는 것 때문이라고 알려져 있다.3,6)

대부분의 연조직 전이는 큰 종물로 구역 림프절에 전이된 종 양으로 나타난다. ${ }^{7)}$ 그래서 주된 임상 양상은 무통성 종물이며, 양성 종양이나 림프절 병증과 감별하기 어렵다. ${ }^{6)}$ 경부에 가장 흔하게 발생하는 곳은 II 구역이며, ${ }^{8)}$ 영상학적 검사로 병변의 범위를 평가하는 것은 유용하지만, 연조직 전이와 림프절 전 이를 구분하는 것은 어렵다. ${ }^{9}$ 종물의 주변에 림프구 침윤 없 이, 연조직 종물만 존재하는 것이 가장 특징적인 병리학적 소 견이다. ${ }^{10)}$

임상 증례가 적어 표준화된 치료는 없으나, 적절한 수술 및 방사선 치료가 생존율을 향상시키고 국소 및 구역 재발을 낮 춘다고 알려져 있다. ${ }^{11)}$ 불량한 전신 상태, 나쁜 조직학적 분화 도 및 진행된 원발암 병기 등은 이런 전이의 가능성을 높이 며, 그 예후는 좋지 않다. ${ }^{8,10)}$ 연조직 전이와 피막외 파급은 유 사한 행동 양식을 가지며 암 발생 초기에 전이가 발생하여, 종 양 세포의 전신 확산에 대한 예측 인자 역할을 한다. ${ }^{411)}$ 그러
므로 연조직 전이의 범위가 제한적이라도 일단 진단되면 반 드시 방사선 치료를 병행해야 된다. ${ }^{11)}$ 그러나 림프절 전이가 1 개이고, 크기가 $3 \mathrm{~cm}$ 미만이며, 피막 외 침범 등이 없는 경 우에는 수술만으로 충분하다는 보고도 있다. ${ }^{11)}$

저자들의 생각으로는 본 증례가 구순암에서 반대측 경부 공간으로 연조직 전이가 발생한 첫 번째 증례 보고라고 생각 된다. 연조직 전이의 존재는 독립적인 음성 예후 인자로, 적극 적인 병합 치료를 시행하여야 생존율을 향상시킬 수 있다. 이 제까지 보고된 증례가 매우 적어, 향후 유사한 증례를 많이 채집하여, 연조직 전이에 대한 임상적 특징 및 표준 치료에 대한 연구가 필수적이라고 사료된다.

\section{REFERENCES}

1) Pastuszek A, Hanson M, Grigg R. Squamous cell carcinoma of the lip: depth of invasion, local recurrence and regional metastases. Experience of a rural multidisciplinary head and neck unit. J Laryngol Otol 2016;130 Suppl 1:S32-7.

2) Huang TY, Hsu LP, Wen YH, Huang TT, Chou YF, Lee CF, et al. Predictors of locoregional recurrence in early stage oral cavity cancer with free surgical margins. Oral Oncol 2010;46(1):49-55.

3) Torigoe T, Terakado A, Suehara Y, Okubo T, Takagi T, Kaneko K, et al. Metastatic soft tissue tumors. J Cancer Ther 2011;2(5):746-51.

4) Jose J, Moor JW, Coatesworth AP, Johnston C, MacLennan K. Soft tissue deposits in neck dissections of patients with head and neck squamous cell carcinoma: prospective analysis of prevalence, survival, and its implications. Arch Otolaryngol Head Neck Surg 2004;130(2): 157-60.

5) Plaza JA, Perez-Montiel D, Mayerson J, Morrison C, Suster S. Metastases to soft tissue: a review of 118 cases over a 30 -year period. Cancer 2008;112(1):193-203.

6) Abed R, Grimer RJ, Carter SR, Tillman RM, Abudu A, Jeys L. Softtissue metastases: their presentation and origin. J Bone Joint Surg Br 2009;91(8):1083-5.

7) Sinha P, Lewis JS Jr, Kallogjeri D, Nussenbaum B, Haughey BH. Soft tissue metastasis in p16-positive oropharynx carcinoma: prevalence and association with distant metastasis. Oral Oncol 2015;51(8):77886.

8) Jose J, Ferlito A, Rodrigo JP, Devaney KO, Rinaldo A, MacLennan K. Soft tissue deposits from head and neck cancer: an under-recognised prognostic factor? J Laryngol Otol 2007;121(12):1115-7.

9) $\mathrm{Ng} \mathrm{SH}, \mathrm{Ko} \mathrm{SF}, \mathrm{Toh} \mathrm{CH}, \mathrm{Chen} \mathrm{YL}$. Imaging of neck metastases. Chang Gung Med J 2006;29(2):119-29.

10) Violaris NS, O'Neil D, Helliwell TR, Caslin AW, Roland NJ, Jones AS. Soft tissue cervical metastases of squamous carcinoma of the head and neck. Clin Otolaryngol Allied Sci 1994;19(5):394-9.

11) Kelder W, Ebrahimi A, Forest VI, Gao K, Murali R, Clark JR. Cutaneous head and neck squamous cell carcinoma with regional metastases: the prognostic importance of soft tissue metastases and extranodal spread. Ann Surg Oncol 2012;19(1):274-9. 